\title{
PEMILIHAN METODE PERBAIKAN DAN PERKUATAN STRUKTUR AKIBAT GEMPA (STUDI KASUS PADA BANK SULTENG PALU)
}

\author{
oleh : \\ Heri Khoeri \\ Teknik Sipil Universitas Muhammadiyah Jakarta \\ Email : hkhoeri@hesa.co.id
}

\begin{abstract}
Abstrak : Sistem Struktur Gedung Kantor Pusat Bank Sulteng, merupakan struktur open frame dengan 1 basement dan 4 lantai di atasnya. Tidak berbeda dengan bangunan di Palu lainnya, bangunan Bank Sulteng (dahulu bernama Bank Pembangunan Daerah Sulawesi Tengah atau BPD Sulteng) pun turut terkena gempa bumi Sulawesi Tengah pada 28 September 2018 yang lalu. Gempa bumi tersebut menimbulkan kekhawatiran kepada para pengguna bangunan bank akan terjadinya kerusakan atau bahkan keruntuhan bangunan saat bangunan tersebut beroperasi. Oleh karena itu, untuk menghindari dan meminimalisir dampak buruk yang mungkin terjadi, maka pada bangunan bank tersebut telah dilakukan pengujian struktur. Setelah diketahui informasi kondisi eksisting bangunan, maka informasi tersebut dapat dijadikan dasar dalam melakukan analisis struktur. Hasil analisis struktur pada laporan akhir assessment yang dilakukan oleh PT. Hesa Laras Cemerlang merekomendasikan beberapa elemen struktur balok dan kolom harus dilakukan perbaikan dan perkuatan. Untuk memilih strategi perbaikan performa seismik dan teknik perkuatan yang tepat harus selain mempertimbangkan faktor kekuatan dan daktilitas struktur untuk menjamin keselamatan penggunanya, juga harus mempertimbangkan biaya, faktor keutamaan bangunan (misalnya bangunan strategis harus memiliki performa yang lebih dibanding rumah tinggal, karena harus tetap berfungsi pasca gempa agar tidak terjadi dampak buruk susulan akibat tidak berfungsinya bangunan strategis tersebut) dan juga aspek kemudahan dalam pelaksanaan. Alternatif perkuatan yang dikaji dalam studi ini adalah perkuatan pada kolom dengan Concrete Jacketing, Steel Jackteting dan FRP (Fyber Reinforced Polymer), dengan batasan alokasi biaya yang sama dilakukan perbandingan pada aspek kekuatan, kemudahan dalam pelaksanaan, waktu pelaksanaan, dan estetika, didapatkan hasil bahwa penggunaan FRP pada studi kasus ini merupakan alternatif yang terpilih.
\end{abstract}

Kata Kunci : Beton, Baja, FRP, Perkuatan, Performa seismik

Abstract : The Central Bank Office Building Structure System in Southeast Sulawesi is an open frame with 1 basement and 4 floors above it. No different with other buildings in Palu, the Central Bank building Southeast Sulawesi (formely known as the Central Sulawesi Regional Development Bank or BPD of Southeast Sulawesi) was also hit by the Central Sulawesi earthquake on September 28, 2018. The earthquake raised concerns for bank building users that the building would be damaged or even collapsed while the building was operating. Therefore, in order to avoid and minimize the bad impacts that may occur, the structure testing has been carried out in the bank building. Once the information on the existing condition of the building is known, this information can be used as a basis for conducting structural analysis. The results of the structural analysis in the final assessment report conducted by PT Hesa Laras Cemerlang recommended that several structural elements of beams and columns should be repaired and retrofitting. In order to choose the appropriate seismic performance improvement strategy and reinforcement technique, besides considering the strength and ductility of the structure to ensure the safety of its users, it must also consider the cost, the priority factor of the building (for example, a strategic building must have more performance than a residential house, because it must continue to function after earthquake so that there will be no further bad impacts due to the malfunction of the strategic building) and also the aspect of ease of implementation. The reinforcement alternatives studied in this study are reinforcement in columns with Concrete Jacketing, Steel Jacketing and FRP (Fyber Reinforced Polymer), with the same cost allocation limitations, comparisons were made on the 
aspects of strength, ease of implementation, implementation time, and aesthetics. The result was that the use of FRP in this case study was the chosen alternative.

Keywords: Concrete, Steel, FRP, Retrofitting, Seismic performa

\section{Pendahuluan}

Hasil analisis struktur pada laporan akhir assessment kantor pusat Bank Sulteng di kota Palu yang dilakukan oleh PT. Hesa Laras Cemerlang pasca terjadinya gempa bumi 28 September 2018 di Palu, merekomendasikan beberapa elemen struktur balok dan kolom harus dilakukan perbaikan dan perkuatan. Dari laporan hasil assessment tersebut direkomendasikan beberapa pilihan perkuatan pada elemen struktur balok dan kolom yang dapat diaplikasikan pada Bangunan Bank Sulteng. Sebelum dilakukan implementasi pekerjaan perbaikan perkuatan, dalam tahap awal (DED) Detail Engineering Design dilakukanlah studi ini untuk melakukan pemilihan alternatif metode perbaikan dengan batasan alokasi biaya yang sama dan aspek yang akan dipertimbangkan lainnya adalah aspek kekuatan, kemudahan dalam pelaksanaan, waktu pelaksanaan, biaya Pelaksanaan dan estetika.

\section{Maksud dan Tujuan Studi Kasus}

Tujuan studi ini adalah untuk dapat menentukan alternatif yang paling tepat untuk perkuatan pada kolom antara metode Concrete Jacketing, Steel Jackteting dan FRP (Fyber Reinforced Polymer), dengan batasan alokasi biaya yang sama dilakukan perbandingan pada aspek kekuatan, kemudahan dalam pelaksanaan, waktu pelaksanaan, biaya pelaksanaan dan estetika.

\section{Landasan Teori}

Untuk struktur gedung yang mengalami kerusakan akibat gempa, selain untuk pengembalian kondisi agar bangunan gedung dapat dipergunakan pasca gempa (post-earthquake rehabilitation), tentu saja perkuatan yang dilakukan harus memenuhi ketentuan dalam peraturan gempa yang terbaru.

Telah banyak dilakukan penelitian untuk mendapatkan metode perkuatan seismik baik untuk perbaikan pre-earthquake maupun perbaikan post-earthquake. Teknikteknik perbaikan yang dikembangkan antara lain adalah dengan mengisi portal dengan beton atau batu bata, dengan memberikan brasing pada portal, dengan menambah kolom, dengan memperbesar kolom (jacketing) baik dengan beton, beton bertulang, baja ataupun dengan Fyber Carbon, dengan memberikan isolasi seismik, dengan mengurangi massa bangunan atau dengan menambah redaman bangunan yang kesemuanya dilakukan untuk mengurangi respons struktur saat gempa dan atau menambah kekuatan struktur.

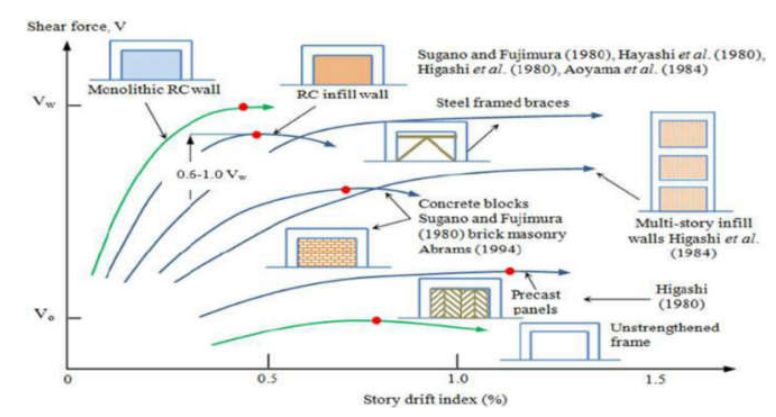

Gambar 1. Tipikal Hubungan Gaya

Geser-Goyangan Lateral Dari Beberapa Perkuatan Portal Beton dengan Berbagai Teknik 


\section{Perkuatan Kolom}

Kolom adalah batang tekan vertikal dari rangka (frame) struktural yang memikul beban dari balok. Karena kolom merupakan komponen tekan, maka keruntuhan pada satu kolom merupakan lokasi kritis yang dapat menyebabkan collapse (runtuh) lantai yang bersangkutan dan juga runtuh batas total (ultimite total collapse) seluruh strukturnya. Oleh karena itu, dalam merencanakan kolom perlu memberikan kekuatan cadangan yang lebih tinggi daripada yang dilakukan pada balok dan elemen struktural horizontal lainnya, terlebih lagi karena keruntuhan tekan tidak memberikan peringatan awal yang cukup jelas. Kolom bersengkang merupakan jenis yang paling banyak digunakan karena murahnya harga pembuatannya.

Triwiyono (2000) menyatakan bahwa perbaikan atau perkuatan struktur atau elemen-elemen struktur diperlukan apabila terjadi degradasi bahan yang berakibat tidak terpenuhi lagi persyaratan-persyaratan yang bersifat teknik yaitu: kekuatan (strength), kekakuan (stiffness), stabilitas (stability) dan ketahanan terhadap kondisi lingkungan (durability). Ada dua jenis perbaikan yang dapat dilakukan dalam pekerjaan retrofitting yaitu repairing dan strengthening.

Istilah repairing diterapkan pada bangunan yang sudah rusak, dimana telah terjadi penurunan kekuatan, untuk dikembalikan seperti semula. Sedangkan strengthening adalah suatu tindakan modifikasi struktur, mungkin belum terjadi kerusakan, dengan tujuan untuk menaikkan kekuatan atau kemampuan bangunan untuk memikul beban-beban yang lebih besar akibat perubahan fungsi bangunan dan stabilitas.

\section{Concrete Jacketing}

Concrete jacketing adalah suatu sistem perkuatan atau perbaikan beton dengan cara menyelimuti beton yang telah ada dengan beton tambahan. Dalam melakukan perkuatan dengan concrete jacketing biasanya digunakan bahan micro concrete yang sifatnya dapat memadat sendiri tanpa bantuan vibrator (self compaction) dimana micro concrete adalah suatu campuran beton dengan ukuran butiran agregat yang kecil (< $0,25 \mathrm{~mm}$ ), agregat yang digunakan sebagai campuran dalam micro concrete ini biasanya adalah pasir silika yang mempunyai gradasi yang heterogen.

Teknik perkuatan struktur ini digunakan pada kolom bangunan yang bertujuan untuk memperbesar penampang kolom, maka penampang kolom menjadi besar dari pada sebelumnya sehingga kekuatan geser beton menjadi meningkat. Agar perkuatan concrete jacketing ini dapat bekerja secara maksimal, maka ada beberapa spesifikasi minimum yang harus dipenuhi. Menurut dokumen CED 39 (7428), spesifikasi minimum yang harus dipenuhi antara lain:

1. Mutu beton pembungkus yang harus lebih besar atau sama dari mutu beton existing

2. Untuk kolom yang tulangan longitudinal tambahan tidak dibutuhkan, minimum harus diberikan tulangan $12 \mathrm{~mm}$ di keempat ujungnya dengan sengkang d8 $\mathrm{mm}$.

3. Minimum tebal jacketing $100 \mathrm{~mm}$

4. Diameter tulangan sengkang minimum d8 mm tidak boleh kurang 1/3 diameter tulangan longitudinal.

5. Jarak maksimal tulangan sengkang pada daerah $1 / 4$ bentang adalah $100 \mathrm{~mm}$, dan jarak vertikal antar tulangan sengkang tidak boleh melebihi $100 \mathrm{~mm}$. 

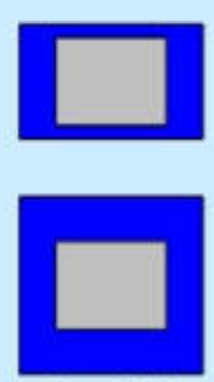

Empat-sisi
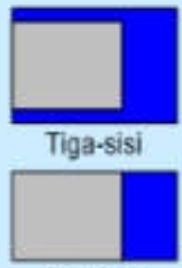

Satu-sisi

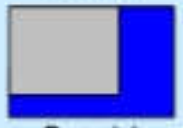

Dua-sisi

Gambar 2. Tampak Atas Beberapa Tipe Kolom dengan Perkuatan Concrete Jacketing

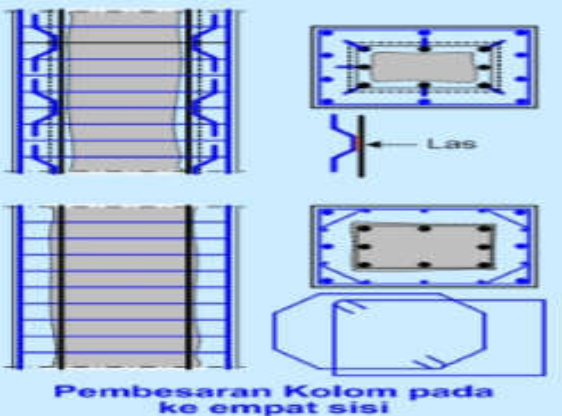

Gambar 3. Detail Concrete Jacketing pada ke Empat Sisinya

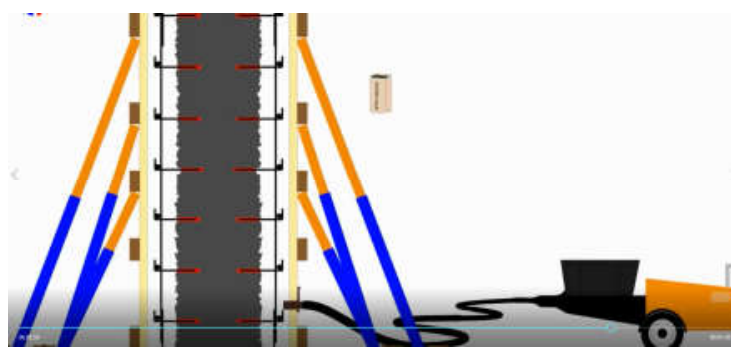

Gambar 4. Pelaksanaan Concrete Jacketing

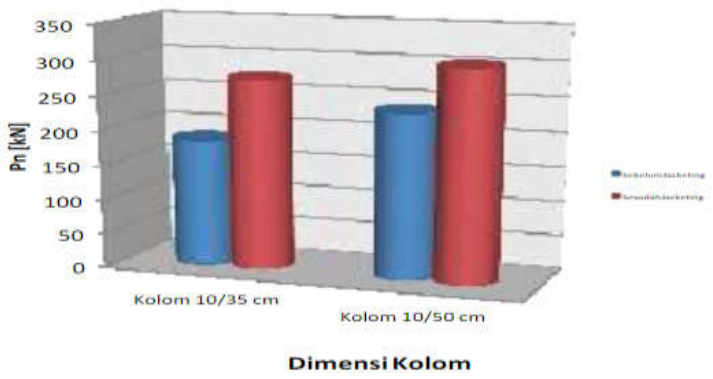

Gambar 5. Grafik Perbandingan Kekuatan Pmaks Kolom Sebelum dan Sesudah Menggunakan Concrete Jacketing

\section{Steel Jacketing}

Montuori, R. dan Piluso, V. menyajikan model teoritis fiber yang dapat memprediksi perilaku kelengkungan momen kolom beton bertulang yang dikekang dengan baja siku dan plat strap. Model yang diajukan telah digunakan untuk memprediksi perbandingan kapasitas daya dukung terhadap beban yang bekerja antara kolom yang tidak diperkuat dan yang diperkuat menggunakan jacketing baja, Elsamny, M.K et al. Jacketing baja adalah suatu teknik untuk memperkuat kolom persegi beton bertulang. Jacketing baja terdiri dari empat sudut baja longitudinal yang ditempatkan di setiap sudut kolom. Sudut longitudinal ini terhubung bersama menjadi sebuah kerangka yang dihubungkan dengan strap baja transversal. Hasil pengujian yang diperoleh menunjukkan bahwa gaya di sudut vertikal di sisi kompresi lebih tinggi daripada di sisi tegangan kolom. Selain itu, gaya pada tali atas lebih tinggi dari pada tali kedua dan tengah.

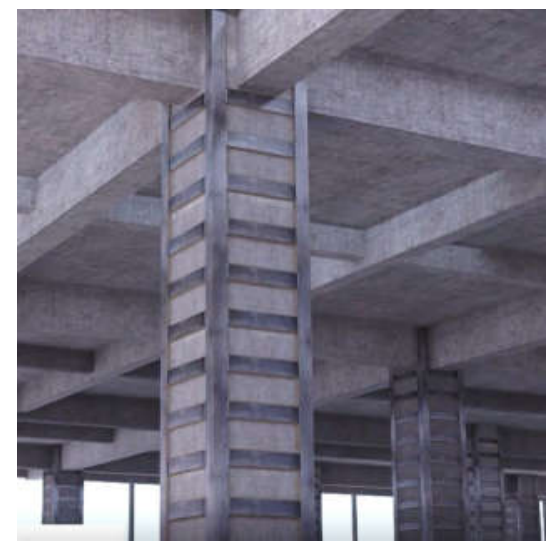

Gambar 6. Ilustrasi Perkuatan Menggunakan Steel Jacketing

Hubungan antara area yang tertutup jaket baja dengan luas permukaan kolom dan peningkatan daya dukung kolom di bawah eksentrisitas yang berbeda berdasarkan hasil pengujian eksperimental seperti ditunjukkan pada gambar berikut. 


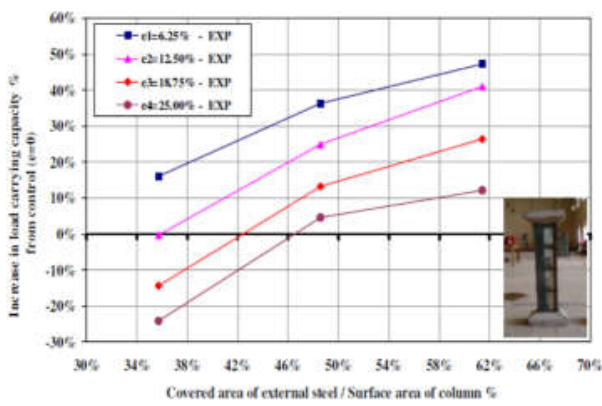

Gambar 7. Hubungan Antara Area yang Tertutup Jaket Baja

Hasil penelitian menunjukkan bahwa meningkatkan area tertutup jacketing baja serta meningkatkan luas penampang baja siku akan meningkatkan kapasitas daya dukung kolom yang diperkuat.

\section{Tabel 1. Dimensi Perkuatan Kolom dengan Menggunakan Steel Jacketing untuk Keperluan Praktis}
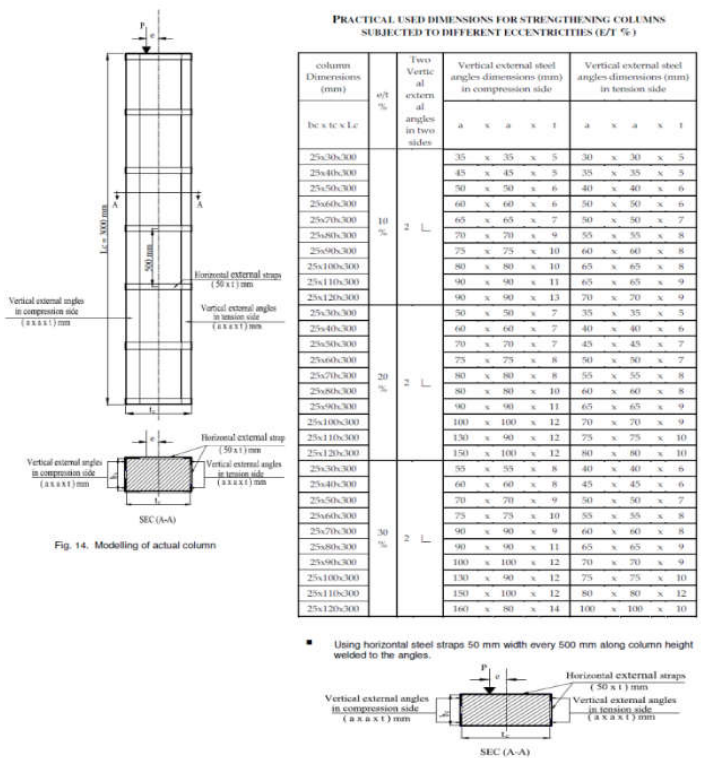

\section{Fiber Carbon}

Carbon fiber didefinisikan sebagai serat yang mengandung setidaknya $90,00 \%$ berat karbon. Umumnya digunakan graphite fiber yang merupakan serat dengan karbon di atas $95,00 \%$ beratnya. Komposit carbon fiber cocok untuk aplikasi struktur yang harus memenuhi persyaratan kekuatan, kekakuan, ringan, dan ketahanan terhadap fatigue. Carbon fiber tidak menunjukkan korosi atau pecah pada suhu kamar. Selain itu juga dapat digunakan dalam aplikasi yang memerlukan ketahanan suhu tinggi, kelembaman dan redaman sehingga material ini cocok digunakan untuk perkuatan kolom.

Konsep pengekangan atau confinement dapat didefinisikan sebagai pembatasan pelebaran lateral beton. Sehingga diharapkan dengan adanya pengekangan yang baik pada struktur maka mampu meningkatkan kekuatan tekan dan regangan aksial ultimit. Dalam penelitian ini akan digunakan dua jenis pengekangan yaitu tulangan baja transversal sebagai internal confinement dan CFRP sebagai external confinement.

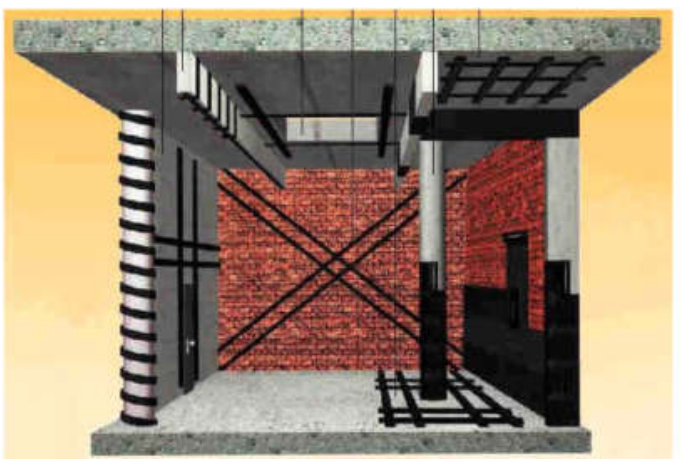

Gambar 8. Perkuatan Struktur dengan FRP

Material FRP yang digunakan adalah

1. Carbon FRP (CFRP)

2. Aramid FRP (AFRP)

3. Glass FRP (GFRP).

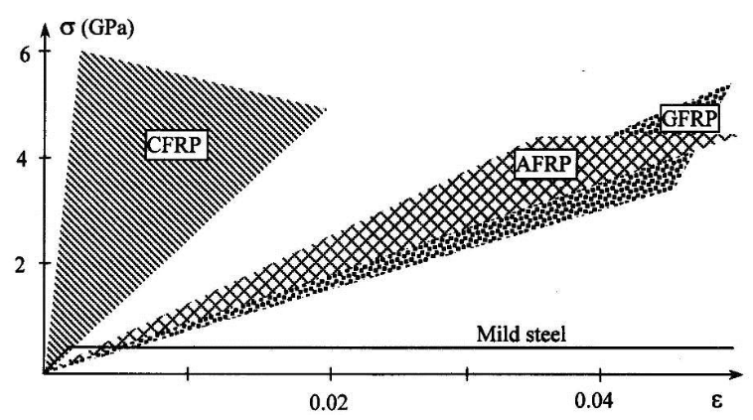

Gambar 9. Diagram Tegangan Regangan 


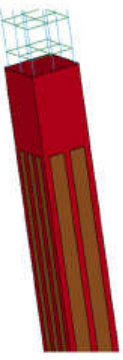

(a)

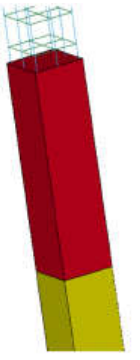

(b)

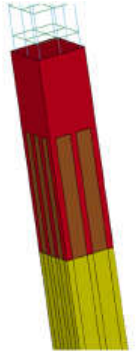

(c)
FRP Strip

FRP wrap
Gambar 10. Perkuatan dengan FRP: (a)

FRP strip; (b) FRP wrap; (c) FRP strip and wrap

\section{Perkuatan Balok}

Perkuatan pada balok akan dilakukan dengan menggunakan fyber carbon.

Sistem perkuatan menggunakan FRP dilakukan dengan cara menempelkannya pada permukaan beton dengan menggunakan perekat epoxy. FRP (Fibre Reinforced Polymer) merupakan bahan yang ringan, kuat, dan tahan terhadap korosi. FRP cukup mudan diaplikasikan pada beton bertulang dan terbukti ekonomis untuk memperbaiki dan meningkatkan kekuatan struktur balok. Secara umum, bahan serat yang digunakan pada FRP ada 3 jenis serat yaitu: carbon, aramid, glass.
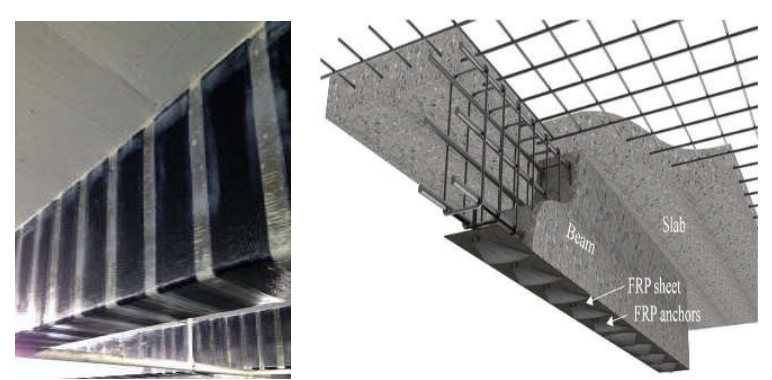

Gambar 11. Perkuatan Balok denga FRP

Overview Hasil dan Rekomendasi Dari Laporan Akhir Assesment

Data Balok yang Harus Diperkuat

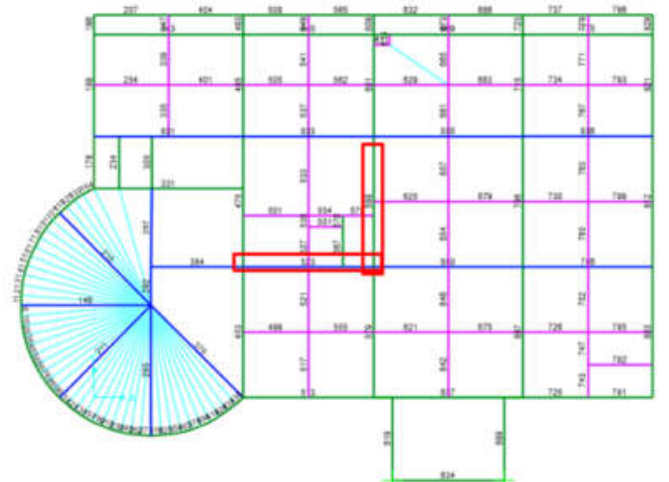

Gambar 12. Denah Balok Lantai 1 (elv$0,00 \mathrm{~m}$ ) yang Harus Diperkuat

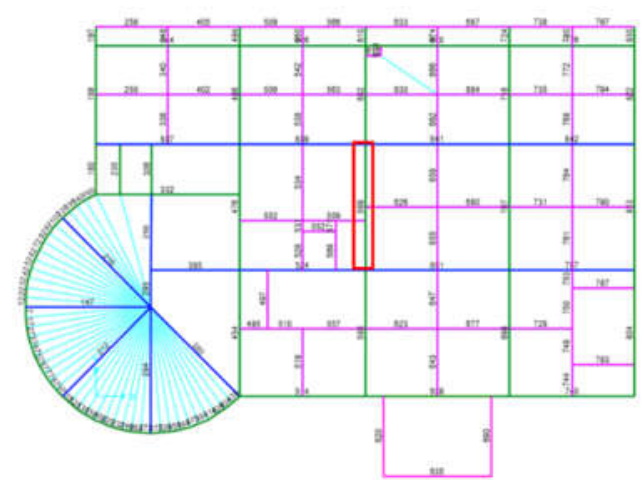

Gambar 13. Denah Balok Lantai 2 (elv4,35 m) yang Harus Diperkuat

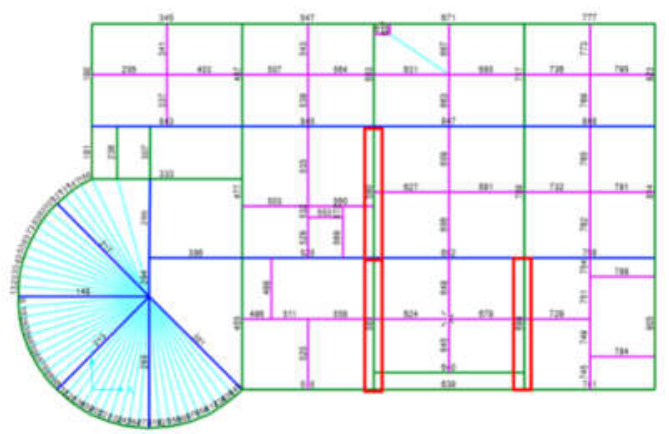

Gambar 14. Denah Balok Lantai (elv-8,7 m) yang Harus Diperkuat

Tabel 2. Data Teknis Balok yang Harus

Diperkuat

\begin{tabular}{|c|c|c|c|c|c|c|}
\hline Frame & $\begin{array}{c}\text { Lengt } \\
\mathbf{h}(\mathbf{m})\end{array}$ & $\begin{array}{c}\text { Dimen } \\
\mathbf{s i} \mathbf{( c m )}\end{array}$ & $\begin{array}{c}\text { Lanta } \\
\mathbf{i}\end{array}$ & $\begin{array}{c}\text { Vma } \\
\mathbf{x} \\
\mathbf{( k N )}\end{array}$ & $\begin{array}{c}\text { Muma } \\
\mathbf{x} \\
\mathbf{( k N m )}\end{array}$ & Failure \\
\hline 523 & 7 & $\begin{array}{c}\mathrm{G} 4 \\
35 / 70\end{array}$ & 1 & 258 & -356 & Geser \\
\hline 588 & 7 & $\begin{array}{c}\mathrm{G} 3 \\
30 / 70\end{array}$ & 1 & -220 & -302 & $\begin{array}{c}\text { Geser dan } \\
\text { Lentur }\end{array}$ \\
\hline
\end{tabular}




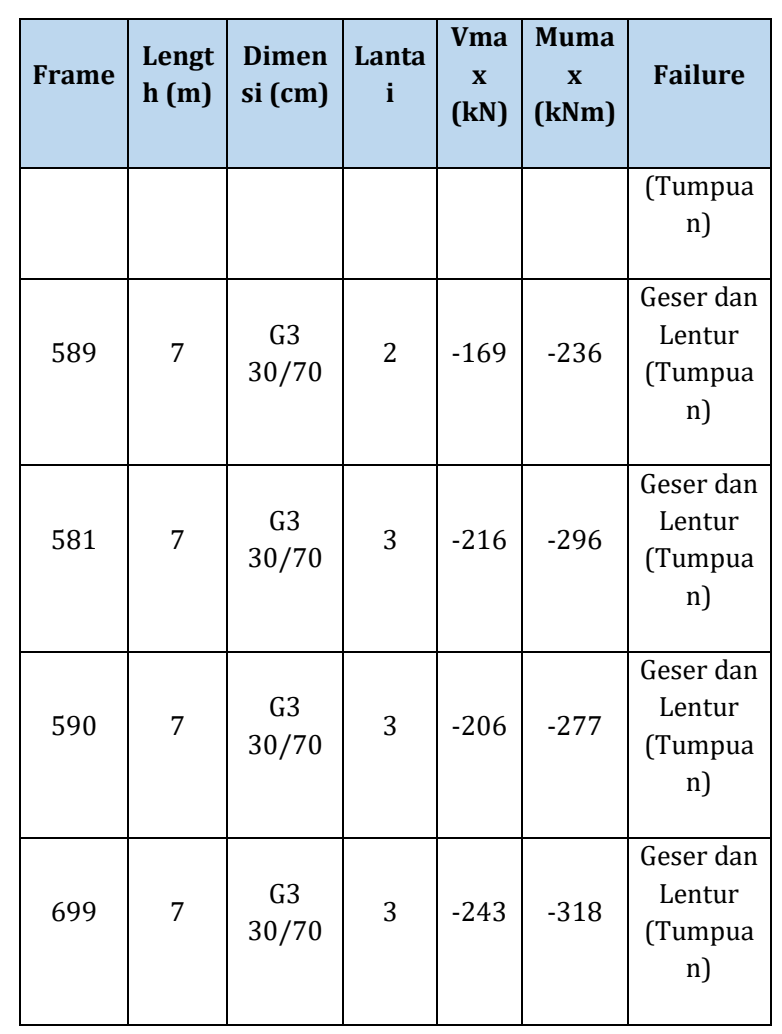

Gambar potongan detail balok yang harus diperkuat seperti gambar berikut:

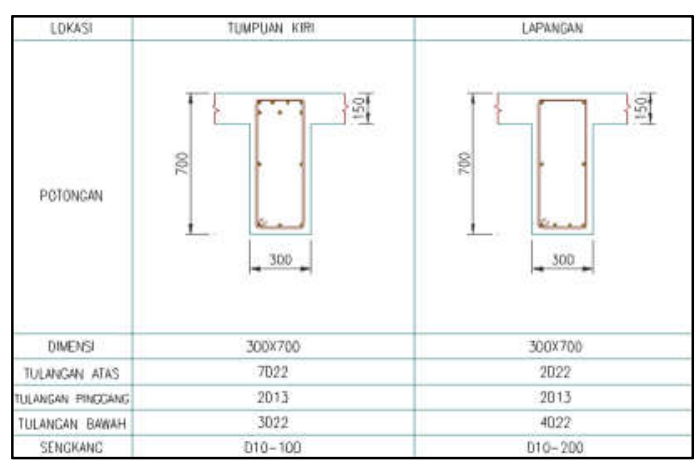

Gambar 15. Detail Balok G3

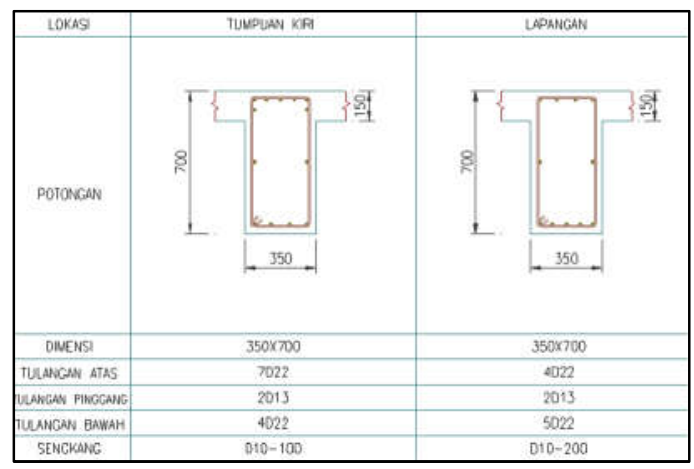

Gambar 16. Detail Balok G4

\section{Perkuatan Balok}

1. Lantai basement $(\mathrm{z}=-3.50)$, tidak mengalami perubahan,

2. Lantai $1(\mathrm{z}=0.00)$,

a. No. balok $=523$, membutuhkan tulangan geser $\emptyset 10-75$.

b. No. balok $=588$, membutuhkan tulangan geser \& torsi $\emptyset 13-50$, dan tulangan memanjang 6D22.

3. Lantai $2(\mathrm{z}=4.35)$,

a. No. balok $=589$, membutuhkan tulangan geser \& torsi $\varnothing 13$ - 50 dan tulangan memanjang 6D22.

4. Lantai $3(\mathrm{z}=8.70)$,

a. No. balok $=581,590$ dan 699 membutuhkan tulangan geser \& torsi $\emptyset 13$ - 50, dan tulangan memanjang 6D22.

5. Lantai $4(\mathrm{z}=13.05)$, tidak mengalami perubahan.

Dapat dilakukan perkuatan dengan menggunakan Fiber Reinforced Polymer (FRP) Sebagai pengganti tulangan geser.

\section{Data Kolom yang Harus Diperkuat}

Tabel 3. Data Teknis Kolom Overstress (fc' = 23,5 MPa)

\begin{tabular}{|c|c|c|c|c|c|c|c|}
\hline Lantai & As & ID & $\begin{array}{l}\text { Tinggi } \\
\text { (m) }\end{array}$ & $\begin{array}{c}\text { Dimensi } \\
\text { (cm) }\end{array}$ & $\begin{array}{c}\text { Pu Max } \\
\text { (kN) }\end{array}$ & $\begin{array}{c}\mathrm{Vu} \\
\mathrm{Max} \\
(\mathrm{kN})\end{array}$ & $\begin{array}{c}\text { Mu Max } \\
\text { (kNm) }\end{array}$ \\
\hline \multirow{14}{*}{1} & $\mathrm{~A} / 4$ & 192 & 4.35 & L60X30 & -170.4 & -7.1 & 17.0 \\
\hline & $\mathrm{B} / 4$ & 489 & 4.35 & $30 / 60$ & -243.0 & 1.4 & -3.4 \\
\hline & $\mathrm{C} / 4$ & 605 & 4.35 & $30 / 60$ & -229.9 & -1.0 & 2.5 \\
\hline & $\mathrm{D} / 4$ & 719 & 4.35 & $30 / 60$ & -241.5 & -0.5 & 1.3 \\
\hline & $E / 4$ & 825 & 4.35 & L60X30 & -192.3 & -0.6 & 1.4 \\
\hline & $E / 3$ & 816 & 4.35 & $30 / 60$ & -199.4 & 0.4 & -1.0 \\
\hline & $A / 3$ & 183 & 4.35 & $30 / 60$ & -153.2 & -0.9 & 2.3 \\
\hline & $E / 2$ & 807 & 4.35 & $30 / 60$ & -210.6 & 0.5 & -1.2 \\
\hline & $E / 1$ & 798 & 4.35 & L60X30 & -129.4 & -5.8 & 13.8 \\
\hline & $D / 1$ & 692 & 4.35 & $30 / 60$ & -513.4 & -15.4 & 15.1 \\
\hline & $\mathrm{C} / 1$ & 574 & 4.35 & $30 / 60$ & -456.7 & 15.5 & -14.6 \\
\hline & $A^{\prime} / 3$ & 309 & 4.35 & L60X30 & -974.7 & 2.3 & -5.3 \\
\hline & $A^{\prime} / 2$ & 301 & 4.35 & L60X30 & -1033.6 & 12.0 & -28.6 \\
\hline & $A / 2^{\prime}$ & 174 & 4.35 & L60X30 & -246.4 & 2.7 & -6.5 \\
\hline \multirow{4}{*}{7} & $\mathrm{~A} / 4$ & 193 & 4.35 & L60X30 & -605.4 & -23.4 & 67.4 \\
\hline & $B / 4$ & 490 & 4.35 & $30 / 60$ & -1024.8 & 8.4 & -20.0 \\
\hline & $\mathrm{C} / 4$ & 606 & 4.35 & $30 / 60$ & -1078.6 & -3.1 & 11.4 \\
\hline & $\mathrm{D} / 4$ & 720 & 4.35 & $30 / 60$ & -1010.4 & 3.2 & 7.4 \\
\hline
\end{tabular}




\begin{tabular}{|c|c|c|c|c|c|c|c|}
\hline Lantai & As & ID & $\begin{array}{c}\text { Tinggi } \\
\text { (m) }\end{array}$ & $\begin{array}{l}\text { Dimensi } \\
(\mathrm{cm})\end{array}$ & $\begin{array}{c}\text { Pu Max } \\
\text { (kN) }\end{array}$ & $\begin{array}{c}\mathrm{Vu} \\
\mathrm{Max} \\
(\mathrm{kN})\end{array}$ & $\begin{array}{c}\text { Mu Max } \\
(\mathrm{kNm})\end{array}$ \\
\hline & $E / 4$ & 826 & 4.35 & L60X30 & -593.4 & -5.1 & 13.7 \\
\hline & $E / 3$ & 817 & 4.35 & $30 / 60$ & -765.5 & 4.2 & -10.3 \\
\hline & $A / 3$ & 184 & 4.35 & $30 / 60$ & -435.2 & -2.4 & 8.9 \\
\hline & $E / 2$ & 808 & 4.35 & $30 / 60$ & -834.5 & 3.6 & -8.4 \\
\hline & $E / 1$ & 799 & 4.35 & L60X30 & -623.0 & -22.3 & 55.5 \\
\hline & $\mathrm{D} / 1$ & 693 & 4.35 & $30 / 60$ & -1065.2 & 6.6 & -21.8 \\
\hline & $C / 1$ & 575 & 4.35 & $30 / 60$ & -989.5 & -4.6 & 20.2 \\
\hline & $A^{\prime} / 3$ & 310 & 4.35 & L60X30 & -731.8 & 1.2 & -2.9 \\
\hline & $A^{\prime} / 2$ & 302 & 4.35 & L60X30 & -741.7 & 11.9 & -27.8 \\
\hline & $A / 2^{\prime}$ & 175 & 4.35 & L60X30 & -427.4 & 5.3 & 12.1 \\
\hline \multirow{14}{*}{3} & $\mathrm{~A} / 4$ & 194 & 4.35 & L60X30 & -363.3 & -39.6 & -87.1 \\
\hline & $B / 4$ & 491 & 4.35 & $30 / 60$ & -592.6 & 9.7 & 23.9 \\
\hline & $\mathrm{C} / 4$ & 607 & 4.35 & $30 / 60$ & -599.3 & 1.7 & -9.4 \\
\hline & $\mathrm{D} / 4$ & 721 & 4.35 & $30 / 60$ & -525.5 & 3.9 & 9,63 \\
\hline & $E / 4$ & 827 & 4.35 & L60X30 & -313.5 & -11.4 & 29.5 \\
\hline & $E / 3$ & 818 & 4.35 & $30 / 60$ & -451.9 & 6.1 & -14.6 \\
\hline & $A / 3$ & 185 & 4.35 & $30 / 60$ & -283.6 & -6.3 & -13.6 \\
\hline & $E / 2$ & 809 & 4.35 & $30 / 60$ & -514.8 & 6.5 & -17.2 \\
\hline & $E / 1$ & 800 & 4.35 & L60X30 & -410.4 & -38.9 & 89.4 \\
\hline & $\mathrm{D} / 1$ & 694 & 4.35 & $30 / 60$ & -639.2 & 3.1 & 17.7 \\
\hline & $\mathrm{C} / 1$ & 576 & 4.35 & $30 / 60$ & -585.6 & -4.2 & -18.8 \\
\hline & $A^{\prime} / 3$ & 311 & 4.35 & L60X30 & -468.2 & 1.7 & 3.9 \\
\hline & $A^{\prime} / 2$ & 303 & 4.35 & L60X30 & -472.5 & 13.8 & -31.9 \\
\hline & $A / 2^{\prime}$ & 176 & 4.35 & L60X30 & $\begin{array}{l}-284.4 \\
\end{array}$ & 3.9 & 9.0 \\
\hline \multirow{14}{*}{4} & $A / 4$ & 195 & 4.35 & L60X30 & -146.9 & -34.9 & -77.1 \\
\hline & $B / 4$ & 492 & 4.35 & $30 / 60$ & -212.5 & 10.1 & -24.1 \\
\hline & $\mathrm{C} / 4$ & 608 & 4.35 & $30 / 60$ & -212.4 & 4.0 & 13.9 \\
\hline & $\mathrm{D} / 4$ & 722 & 4.35 & $30 / 60$ & -215.7 & 9.1 & -24.0 \\
\hline & $E / 4$ & 828 & 4.35 & L60X30 & -130.7 & -16.0 & -35.0 \\
\hline & $E / 3$ & 819 & 4.35 & $30 / 60$ & -170.3 & 3.4 & 10.5 \\
\hline & $A / 3$ & 186 & 4.35 & $30 / 60$ & -111.0 & -7.5 & 17.3 \\
\hline & $E / 2$ & 810 & 4.35 & $30 / 60$ & -169.7 & 6.9 & 17.4 \\
\hline & $E / 1$ & 801 & 4.35 & L60X30 & -148.9 & -39.3 & -91.0 \\
\hline & $\mathrm{D} / 1$ & 695 & 4.35 & $30 / 60$ & -205.7 & -6.2 & -16.5 \\
\hline & $C / 1$ & 577 & 4.35 & $30 / 60$ & -203.0 & 8.6 & 19.4 \\
\hline & $A^{\prime} / 3$ & 312 & 4.35 & L60X30 & -195.2 & 1.6 & 3.9 \\
\hline & $\mathrm{A}^{\prime} / 2$ & 304 & 4.35 & L60X30 & -209.4 & 15.3 & -33.6 \\
\hline & $A / 2^{\prime}$ & 177 & 4.35 & L60X30 & -107.0 & 5.8 & -14.8 \\
\hline
\end{tabular}

c. untuk level lantai 2 - lantai $3(\mathrm{z}=4.35$ $\mathrm{s} / \mathrm{d} \mathrm{z}=8.70$ ), 12 D 22.

d. untuk level lantai 3 - lantai $4(\mathrm{z}=8.70$ $\mathrm{s} / \mathrm{d} \mathrm{z}=13.05$ ), juga $12 \mathrm{D} 22$.

2. K10 : diperbaiki menjadi K45/45, dengan penulangan sebagai berikut,

a. untuk level Basement - lantai $1(\mathrm{z}=$ $3.50 \mathrm{~s} / \mathrm{d} \mathrm{z}=0.00), 20 \mathrm{D} 22$.

b. untuk level lantai 1 - lantai $2(\mathrm{z}=0.00$ $\mathrm{s} / \mathrm{d} \mathrm{z}=4.35), 16 \mathrm{D} 22$.

c. untuk level lantai 2 - lantai $3(\mathrm{z}=4.35$ $\mathrm{s} / \mathrm{d} \mathrm{z}=8.70$ ), 12 D 22.

d. untuk level lantai 3 - lantai $4(\mathrm{z}=8.70$ $\mathrm{s} / \mathrm{d} \mathrm{z}=13.05$ ), juga $12 \mathrm{D} 22$.

\section{Perbandingan kemudahan dalam Pelaksanaan}

\section{Concrete jacketing}

Pelaksanaan concrete jacketing sebenarnya tidak ada masalah untuk dilaksanakan, namun kesulitan akan muncul ketika melakukan penggalian tanah untuk memperbesar kolom sampai ke pondasi telapak. Karena pembesaran kolom yang diperbesar mulai 1.33 hingga 2 kali dari kolom eksisting harus filakukan sampai ke pondasi telapak yang berada $4 \mathrm{~m}$ di bawah basement.

\section{Rekomendasi Perkuatan Kolom}

Kolom diperbesar menjadi $60 \mathrm{~cm}$ x $60 \mathrm{~m}$ dengan beton material beton low shrinkage minimal K-300

1. K5, K2, K4 : diperbaiki menjadi K60/60, dengan penulangan sebagai berikut,

a. Untuk level Basement - lantai $1(\mathrm{z}=$ $3.50 \mathrm{~s} / \mathrm{d} \mathrm{z}=0.00), 20 \mathrm{D} 22$.

b. Untuk level lantai 1 - lantai $2(\mathrm{z}=0.00$ $\mathrm{s} / \mathrm{d} \mathrm{z}=4.35), 16 \mathrm{D} 22$. 


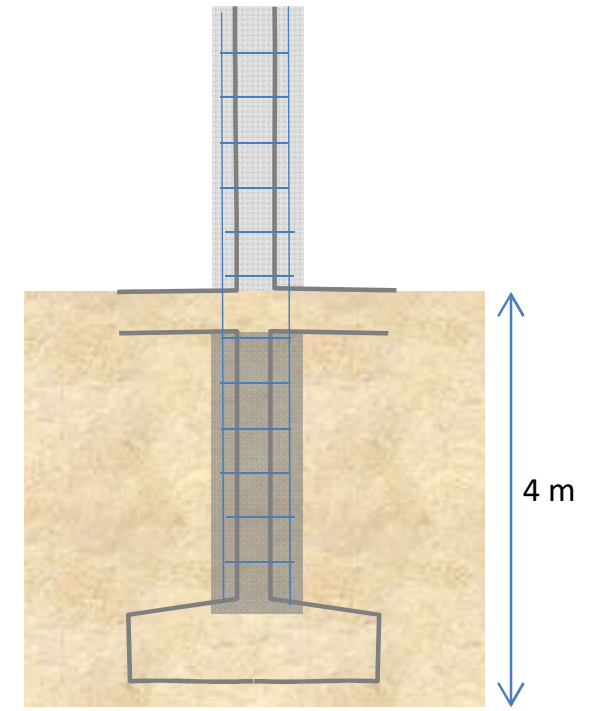

Gambar 17. Sketsa Perkuatan Kolom dengan Concrete Jacketing pada Bagian Bawah

Penggalian tanah sedalam $4 \mathrm{~m}$, dengan menjebol pelat lantai basement memang bisa dilakukan tapi tentunya akan memakan waktu, sehingga perlu dipertimbangkan alternatif lain, selain juga pertimbangan masalah safety dan pembuatan turap sementara selama dilakukan pekerjaan concrete jacketing.

2. Steel jacketing

Pelaksanaan steel jacketing lebih mudah untuk dilaksanakan dibandingkan concrete jacketing karena jacketing tidak perlu dilakukan sampai ke pondasi. Pemasangannya butuh tingkat keahlian presisi yang tinggi sehingga antara baja dan beton dapat disatukan dengan epoxy grouting dengan baik.

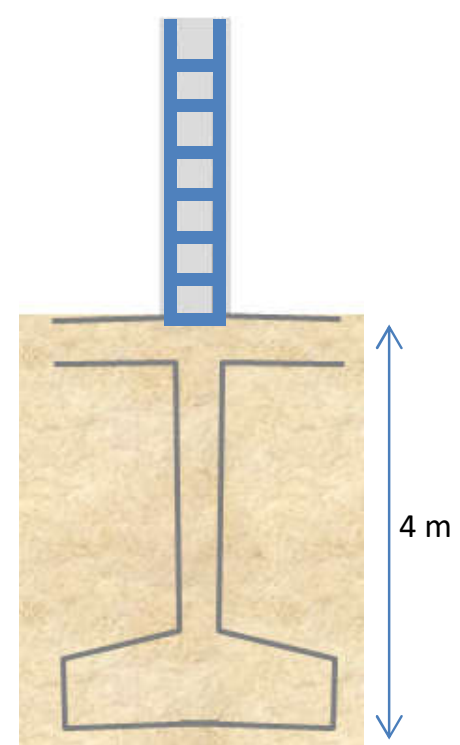

\section{Gambar 18. Sketsa Perkuatan Kolom dengan Steel Jacketing pada Bagian Bawah}

3. Fyber carbon

Pelaksanaan pemasangan fyber carbon dapat dilakukan dengan lebih cepat dan dan mudah dibandingkan concrete jacketing ataupun steel jacketing, paling minimal gangguan pada operasinya bangunan dan tidak memerlukan area kerja yang luas.

\section{Perbandingan Waktu Pelaksanaan}

1. Concrete jacketing

Dengan melihat tingkat kesulitan pada saat pelaksanaan, pengerjaan jacketing beton memerlukan waktu 1,5 (satu setengah) bulan sendiri untuk melakukan penggalian dan jacketing kolom di bawah pelat basement sampai ke pondasi. Selanjutnya pekerjaan lainnya diperkirakan memerlukan waktu 0,75 bulan per lantainya. Dan pekerjaan testing dan finishing 0,5 bulan. Jadi perkiraan waktu pelaksanaan adalah 5 (lima) bulan.

2. Steel jacketing

Pekerjaan steel jacketing akan lebih cepat dari concrete jacketing karena tidak perlu melakukan perkuatan 
sampai ke pondasi telapak. Pekerjaan persiapan dan pengiriman material diperkirakan 0.5 (setengah) bulan. Selanjutnya pekerjaan jacketing per lantai memerlukan waktu 0,75 bulan per lantainya. Dan pekerjaan testing dan finishing 0,5 bulan. Jadi perkiraan waktu pelaksanaan adalah 4 (empat) bulan.

3. Fyber carbon

Pekerjaan perkuatan dengan fiber carbon paling cepat diantara alternatif lainnya karena selain tidak perlu melakukan perkuatan sampai ke pondasi telapak, tidak memerlukan bekisting dan sedikit injeksi dan grouting (hanya paa bagian-bagian yang terindikasi mutu betonnya kurang bagus saja). Pekerjaan persiapan dan pengiriman material diperkirakan 0.5 (setengah) bulan. Selanjutnya pekerjaan jacketing per lantai memerlukan waktu 0,5 bulan per lantainya. Dan pekerjaan testing dan finishing 0,5 bulan. Jadi perkiraan waktu pelaksanaan adalah 3 (tiga) bulan.

\section{Perbandingan Biaya}

Perkiraan biaya pelaksanaan perbaikan dan perkuatan dengan ketiga alternatif metode adalah sebagai berikut:

1. Concrete jacketing: Rp.

3,543,100,000.000

2. Steel jacketing: Rp. $3,529,900,000$

3. Fyber carbon: Rp. $3,558,500,000$

\section{Perbandingan Estetika}

Perbandingan secara estetika disini dengan membandingkan efek perubahan pada tampak secara arsitektur dengan adanya perubahan bentuk akibat adanya tambahan perkuatan.

Dari ketiga alternatif perkuatan FRP paling minimal dalam merubah bentuk asli dimensi elemen struktur sehingga minimal dalam merubah luasan ruang yang dapat dimanfaatkan.

\section{Kesimpulan}

Dari ketiga alternatif perkuatan dalam studi ini yaitu perkuatan pada kolom dengan Concrete Jacketing, Steel Jackteting dan FRP (Fyber Reinforced Polymer), dengan batasan alokasi biaya yang sama dimana dilakukan perbandingan antara ketiganya pada aspek kekuatan, kemudahan dalam pelaksanaan, waktu pelaksanaan, dan estetikanya, dapat disimpulkan bahwa:

1. Steel jacketing memiliki keunggulan pada aspek peningkatan kekuatan dan penambahan kekakuan dibandingkan dua alternatif lainnya.

2. FRP memiliki keunggulan dibandingkan kedua alternatif lainnya dalam hal kemudahan pelaksanaan, waktu pelaksanaan dan estetika. Walaupun dari sisi harga relatif paling mahal namun dalam studi ini sudah dibatasi kisaran alokasi biayanya.

3. Concrete jacketing memiliki kinerja yang paling baik dalam penambahan kekakuan struktur namun dalam kasus studi ini, concrete jacketing memiliki kelemahan pada tingkat kemudahan pada pelaksanaan sehingga berdampak pada waktu pelaksanaan yang lebih lama. Begitupun dari aspek biaya sebenarnya relatif paling murah, namun dalam studi ini sudah dibatasi kisaran alokasi biayanya.

4. Dengan pertimbangan pada aspek kekuatan, kemudahan dalam pelaksanaan, kecepatan waktu pelaksanaan dan estetika pada kisaran alokasi biaya yang sama, maka FRP merupakan alternatif terpilih, seperti ditunjukkan pada Matriks scoring pemilihan alternatif di bawah ini 
Tabel 4. Matriks Scoring Pemilihan Alternatif

\begin{tabular}{|c|c|c|c|c|c|}
\hline $\begin{array}{c}\text { Type } \\
\text { Perkuatan }\end{array}$ & Kekuatan & $\begin{array}{c}\text { Kemudahan } \\
\text { Pelaksanaan }\end{array}$ & $\begin{array}{c}\text { Waktu } \\
\text { Pelaksanaan }\end{array}$ & Estetika & Total \\
\cline { 2 - 6 } Score \\
\hline $\begin{array}{c}\text { Concrete } \\
\text { Jacketing }\end{array}$ & 2 & 1 & 1 & 1 & 6 \\
\hline $\begin{array}{c}\text { Steel } \\
\text { Jacketing }\end{array}$ & 3 & 2 & 2 & 2 & 9 \\
\hline $\begin{array}{c}\text { Fyber } \\
\text { Carbon }\end{array}$ & 1 & 3 & 3 & 3 & 10 \\
\hline
\end{tabular}

\section{Daftar Pustaka}

Elsamny, M.K., Ibrahim, M.A., Elesnawi, H.H. and Oudah, H.K.. Behaviour of Steel Jackets Used In Strengthening Columns Subjected To Eccentric Loading. Journal of Al Azhar University Engineering Sector ( JAUES ) Faculty Of Engineering, Al-Azhar University, Cairo, Egypt, Vol. 6, No. 19, PP. 493-514, 2011.

Ezz-Eldeen, H. A.. Steel Jacketing Technique used in Strengthening Reinforced Concrete Rectangular Columns under Eccentricity for Practical Design Applications. International Journal of Engineering Trends and Technology (IJETT) - Volume 35 Number 5- May 2016.

Hesa Laras Cemerlang, PT., 2018. Laporan Akhir Hasil Assessment Bank Sulteng Pasca Terjadinya Gempa Bumi.

Jenefer Teofany Kaontole M. D. J. Sumajouw, R. S. Windah,. Evaluasi Kapasitas Kolom Beton Bertulang Yangdiperkuat Dengan Metode Concrete Jacketing. Universitas Sam Ratulangi Fakultas Teknik Jurusan Sipil Manado, 2015.

Montuori, R. and Piluso, V. Reinforced concrete columns strengthened with angles and battens subjected to eccentric load. Elsevier Ltd., Engineering Structures 31- PP.539-550, 2009.
Sugano, S., 1996. The State of Art in Techniques for Rehabilitation of Buildings, Elsevier Science Ltd.

Triwiyono A, Wikana I, 2000. Kuat Geser Kolom Beton Bertulang Penampang Lingkaran yang Diperbaiki dengan Metode Concrete Jacketing. Tesis Program Studi Teknik Sipil Program Pasca sarjana Universitas Gadjah Mada Yogyakarta. 
